\title{
Efektivitas enzim kasar kitinase dari jamur Trichoderma viride yang diiradiasi oleh sinar gamma terhadap degradasi cangkang telur nematoda Haemonchus contortus pada ternak domba
}

\section{Effectiveness of chitinase crude enzymes from Trichoderma viride fungi irradi- ated by gamma rays on the degradation of Haemonchus contortus nematode eggshell in sheep}

\author{
Devi Indrawati ${ }^{1}$, Ari Susilowati ${ }^{1 *}$ Dadang Priyo Atmojo $^{2}$, Nana Mulyana ${ }^{2}$ \\ ${ }^{1}$ Program Studi Biologi FMIPA Universitas Sebelas Maret, Surakarta \\ ${ }^{2}$ Pusat Aplikasi Isotop dan Radiasi, Badan Tenaga Nuklir Nasional, Jakarta
}

Submitted: 18 September 2018, Accepted: 18 Januari 2019

\begin{abstract}
ABSTRAK: Tujuan dari penelitian ini adalah untuk mengetahui efek peningkatan aktivitas enzim kasar kitinase yang dihasilkan oleh Trichoderma viride menggunakan berbagai variasi dosis iradiasi gamma terhadap degradasi kulit telur Haemoncus contortus. Telur Haemoncus contortus diisolasi dari tinja domba menggunakan metode sentrifugasi apung. Uji kualitatif enzim kitinase dilakukan dengan menginokulasi Trichoderma viride yang telah diiradiasi sinar gamma dengan dosis kontrol 250 Gray, 500 Gray, 750 Gray dan 1000 Gray pada media koloidal kitin agar. Uji kuantitatif dilakukan dengan mengukur aktivitas enzim kitinase menggunakan metode kolorimetrik berdasarkan aktivitas enzim spesifik dan penentuan kadar protein terlarut. Perubahan cangkang diamati secara mikroskopis sementara kadar $\mathrm{N}$-asetil glukosamin dan kadar protein terlarut diukur menggunakan spektrofotometer. Data dianalisis menggunakan One Way Analysis of Variance (ANOVA) dengan taraf kepercayaan 95\% dan dilanjutkan dengan Duncan's Multiple Range Test. Hasil penelitian menunjukkan bahwa perlakuan dosis iradiasi gamma meningkatkan aktivitas enzim kasar kitinase yang dihasilkan oleh Trichoderma viride. Pada dosis 500 Gray Trichoderma viride memiliki aktivitas spesifik kitinase optimum dengan konsentrasi 0,30 U/mg. Lebih lanjut, enzim kasar kitinase efektif mendegradasi semua lapisan kulit telur Haemoncus contortus dan semakin tinggi konsentrasi enzim kasar yang diberikan, semakin besar pula tingkat kerusakan lapisan telur.
\end{abstract}

Kata kunci : degradasi cangkang telur; enzim kasar kitinase; Haemonchus contortus; iradiasi sinar gamma; nematoda; Trichoderma viride

ABSTRACT: The aim of this study was to determine increasing of chitinase crude enzyme activity produced by Trichoderma viride at different gamma irradiation doses and to know the degradation on the eggshell of Haemonchus contortus. Eggs of Haemonchus contortus were isolated from sheep feces using buoyant centrifugation method. The qualitative test of chitinase was conducted by inoculating Trichoderma viride irridiated by variation gamma doses control, 250 Gray, 500 Gray, 750 Gray and 1000 Gray on the media of colloidal chitin agar. The quantitative test was conducted by measuring chitinase activity using colorimetric method based on specific enzyme activity and determination of dissolved protein levels. Shell changes were observed microscopically while N-acetyl glucosamine levels and dissolved protein levels were measured using spectrophotometer. Data were analyzed using One Way Analysis of Variance (ANOVA) with significance of the $95 \%$ and continued with Duncan's Multiple Range Test (DMRT test). The results showed that gamma irradiation doses treatment increase of chitinase crude enzyme activity produced by Trichoderma viride. At a dose of 500 Gray, Trichoderma viride had the optimum chitinase specific activity i.e. $0.30 \mathrm{U} / \mathrm{mg}$. Furthermore, chitinase crude enzyme effective to degrade all layers of the eggshell of Haemonchus contortusand the higher the concentration of crude enzyme given, the greater the level of egg damaged.

Keywords : chitinase crude enzyme; eggshell degradation; gamma irradiation; Haemonchus contortus; nematode; Trichoderma viride.

*Corresponding Author: arisusilowati@staff.uns.ac.id

DOI: 10.21776/ub.jiip.2019.029.01.04 


\section{PENDAHULUAN}

Kesehatan ternak merupakan salah satu faktor yang dapat menentukan produktivitas ternak. Timbulnya penyakit pada ternak dapat menyebabkan menurunnya produktivitas ternak sehingga menyebabkan kerugian secara ekonomi di bidang peternakan (Kertawirawan, Yasa, dan Adijaya, 2012). Haemonchus contortus merupakan salah satu parasit nematoda yang menyerang saluran pencernaan ruminansia kecil sehingga dapat menyebabkan nematodiasis. Di Indonesia kerugian akibat parasit nematode pada pada kambing ditaksir mencapai 7 miliar per tahun (Ahmad dkk., 2006). Tehrani et al. (2012) dalam penelitiannya mengatakan bahwa pada tahun 2010 dan 2011 prevalensi infeksi Haemonchus contortus pada domba di Iran yaitu $93 \%$.

Pengendalian Haemonchus contortus yang umum dilakukan adalah melalui pemberian antihelmintik, vaksinasi serta suplemen nutrisi (Subandriyo, Suhardono, and Gray, 2004). Pengendalian dengan antihelmitik dapat menyebabkan efek resistensi pada agen parasit dan residu inang bila digunakan dalam jangka waktu yang lama (Ahmad, 2013), sehingga diperlukan pengendalian secara alami melalui agen hayati yaitu menggunakan kapang (Ahmad, 2011). Telur nematoda merupakan fase terpenting dalam siklus nematoda yang bisa menjadi target pengendalian dibandingkan pada fase larva. Cangkang telur nematoda terdiri atas 3 lapisan yaitu lapisan protein (vitelin), kitin dan lipid (Mansfield, Gamble, and Fetterer,1992). Secara umum produksi kitinase diikuti oleh produksi protease. Protease mampu menghilangkan lapisan protein. Sedangkan kitinase dapat mendegradasi lapisan kitin yang merupakan struktur penting pada cangkang telur (Gortari and Hours, 2008).

Pada penelitian ini digunakan kapang Trichoderma viride yang telah diiradiasi sinar gamma. Kapang Trichoderma sp. diketahui memiliki aktivitas kitinase dan protease (Gortari and Hours, 2008) melalui iradiasi dengan sinar gamma. Mutasi yang diakibatkan oleh iradiasi gamma dapat menyebabkan kapang terinduksi untuk menghasilkan aktivitas enzim lebih tinggi dari pada sebelum diiradiasi dengan sinar gamma (Nanda and Abraham, 2013). Menurut Larasati, dkk (2016), iradiasi kapang pada sinar gamma dosis rendah dapat menstimulasi peningkatan aktivitas enzim oleh mikroba. Penelitian ini bertujuan untuk mengetahui efek peningkatan aktivitas enzim kasar kitinase yang dihasilkan Trichoderma viride pada dosis iradiasi gamma yang berbeda terhadap degradasi cangkang telur Haemonchus contortus oleh enzim kasar kitinase Trichoderma viride pada konsentrasi yang berbeda.

\section{MATERI DAN METODE \\ Bahan dan Alat}

Bahan-bahan yang digunakan terdiri dari tinja kambing, kultur kapang Trichoderma viride, Potato Dextrose Agar (PDA), Bromo Cresol Purple (BCP), Substrat kitin cangkang udang, Potato Dextrose Broth (PDB), N-Asetil Glukosamine, Agar, Potassium tetraborat, pdimetilaminobenzaldehida (DMAB), $\mathrm{HCl}$ (p.a), $\mathrm{NaOH}$ (p.a), Folin Ciocalteau, Sodium Pottasium Tartrat, Asam Sitrat, Etanol, Buffer Fosfat, Pepton, Yeast Extract, $\left(\mathrm{NH}_{4}\right)_{2} \mathrm{SO}_{4}$, $\mathrm{KH}_{2} \mathrm{PO}_{4}$ (p.a), $\mathrm{MgSO}_{4} .7 \mathrm{H}_{2} \mathrm{O}$ (p.a), $\mathrm{NaCl}$ (p.a), $\mathrm{CuSO}_{4}, \mathrm{Na}_{2} \mathrm{CO}_{3}$, Aquades. Peralatan yang digunakan meliputi cawan Petri, tabung reaksi, Erlenmeyer, gelas beker, shaker mekanis, autoklaf (Wise), inkubator (Heracus), laminar air flow (Panasonic), $\mathrm{pH}$ meter, microcentrifuge (Sorvall), centrifuge Himac CR21GII (Hitachi), bunsen, mikroskop, Atomic Absorption Spectrophotometer (Parkin Elmer), irradiator (Gamma Chamber 4000A). 


\section{Isolasi telur cacing}

Telur diisolasi dengan metode sentrifugasi apung. Tinja domba sebanyak 2 gram, dihaluskan dan diencerkan dengan $50 \mathrm{ml}$ aquades, kemudian disentrifus selama 5 menit. Pelet ditambahkan $\mathrm{NaCl}$ jenuh sebanyak $20 \mathrm{ml}$ dan disentrifus. $\mathrm{NaCl}$ jenuh ditambahan ke dalam tabung yang berisi pellet hingga permukaan cairan menjadi cembung dan ditunggu selama 10 menit. Telur akan mengapung ke atas bibir tabung kemudian gelas obyek ditempelkan pada permukaan cairan dan dicuci menggunakan akuades. Cairan yang berisi telur ditampung pada cawan petri dan diamati di bawah mikroskop cahaya dengan perbesaran 4x hingga 10x. Telur Haemonchus contortus yang sudah dikoleksi disimpan di dalam kulkas dengan suhu $4^{\circ} \mathrm{C}$ (Dunn, 1978; Natadisastra and Agoes, 2009).

\section{Perlakuan kapang Trichoderma viride menggunakan iradiasi sinar gamma}

Kapang Trichoderma viride dalam media PDA pada cawan petri yang berumur 47 hari diiradiasi dengan sinar gamma dengan cara dipapar pada dosis 250, 500, 750, dan 1000 Gray dengan lama penyinaran 15 menit. Kapang Trichoderma viride tanpa perlakuan iradiasi sinar gamma digunakan sebagai kontrol. Kultur kapang Trichoderma viride dikultivasi ke dalam 25 $\mathrm{ml}$ media yang mengandung $12 \mathrm{~g} / \mathrm{l}$ PDB kemudian diinkubasi pada suhu $32{ }^{\circ} \mathrm{C}$ selama 4 hari sehingga diperoleh kultur cair atau starter, perlakuan dilakukan sebanyak 2 ulangan (Wahyudi dkk, 2005). Starter digunakan untuk memproduksi enzim kasar kitinase.

\section{Uji aktivitas kitinolitik kapang Tricho- derma viride pada media koloidal kitin agar}

Media koloidal kitin pH 7 dibuat dengan komposisi $\mathrm{MgSO}_{4} 0,15 \mathrm{~g},\left(\mathrm{NH}_{4}\right) \mathrm{SO}_{4}$ 1,5 g,
$\mathrm{KH}_{2} \mathrm{PO}_{4} 1 \mathrm{~g}$, Asam sitrat 0,5 g, Agar $7 \mathrm{~g}$, Koloidal kitin 5\% $40 \mathrm{ml}$, NA 1,6 g, Bromo Cresol Purple 0,15 g, akuades $80 \mathrm{ml}$ kemudian disterilkan dengan autoclave. Kultur kapang Trichoderma viride dalam media PDA dipindah tanamkan pada media koloidal kitin agar. Selanjutnya diinkubasi pada suhu $30^{\circ} \mathrm{C}$ selama 4 hari. Perubahan warna ungu pada media menunjukkan bahwa kapang Trichoderma viride memiliki aktivitas kitinolitik (Gomez et al., 2004; Agrawal and Kotasthane, 2012).

\section{Produksi enzim kasar kitinase}

Media produksi dengan $\mathrm{pH} 7$ mengandung PDB 2,4 g, $\left(\mathrm{NH}_{4}\right)_{2} \mathrm{SO}_{4} 1,5 \mathrm{~g}, \mathrm{KH}_{2} \mathrm{PO}_{4}$ $1 \mathrm{~g}$, Ekstrak yeast $1 \mathrm{~g}$, Pepton $1 \mathrm{~g}$, $\mathrm{MgSO}_{4} .7 \mathrm{H}_{2} \mathrm{O} 0,15 \mathrm{~g}$, dan $\mathrm{NaCl} 1 \mathrm{~g}$, koloid kitin 5\% sebanyak $50 \mathrm{ml}$, disterilkan dengan autoclave. Sebanyak $1500 \mu 1$ kultur cair Trichoderma viride diinokulasikan kedalam $30 \mathrm{ml}$ media produksi kitinase. Selanjutnya diinkubasi pada suhu $28-32^{\circ} \mathrm{C}$ selama 2 hari, ekstraksi enzim dilakukan dengan cara sentrifugasi pada $12.000 \mathrm{rpm}$ pada suhu $4^{\circ} \mathrm{C}$ selama 10 menit (Narasimhan et al., 2013; Wirawan and Herdyastuti, 2013). Supernatan yang dihasilkan merupakan ekstrak enzim kasar kitinase.

\section{Degradasi cangkang telur Haemonchus contortus}

Enzim kasar kitinase dengan nilai aktivitas enzim yang optimal digunakan dalam degradasi cangkang telur yang dibuat dengan beberapa variasi konsentrasi. Konsentrasi enzim dibuat menggunakan enzim kasar kitinase dengan akuades steril. Konsentrasi yang digunakan yaitu $0,06,0,12$, $0,18,0,24$ dan $0,3 \mathrm{U} / \mathrm{ml}$. Untuk kontrol, telur tidak diberi perlakuan enzim kasar kitinase. Perlakuan dilakukan dengan 3 kali pengulangan. Cawan petri yang berisi $4 \mathrm{ml}$ akuades steril yang mengandung 20 telur ditambahkan dengan enzim kasar kitinase 
dengan konsentrasi yang berbeda dan diinkubasi pada suhu $30^{\circ} \mathrm{C}$ selama 48 jam. Perubahan yang terjadi pada telur diamati setelah 48 jam dengan menggunakan mikroskop cahaya perbesaran $4 \mathrm{x}$ dan $10 \mathrm{x}$ (Lobna and Zawam, 2010). Selain itu dilakukan pengukuran kadar $\mathrm{N}$-asetil glukosamin dan kadar protein terlarut (Muzarelli and Peter, 1997).

\section{Pengukuran Aktivitas Enzim Kitinase}

Supernatan enzim kasar sebanyak 500 $\mu \mathrm{l}$ ditambahkan $500 \mu \mathrm{l}$ 0,5\% koloidal kitin dalam $0,1 \mathrm{M}$ bufer fosfat $(\mathrm{pH} \mathrm{7})$ dan diinkubasi pada suhu $37^{\circ} \mathrm{C}$ selama 30 menit lalu disentrifugasi. Supernatan sebanyak $500 \mu \mathrm{l}$ ditambah dengan $100 \mu \mathrm{l}$ potassium tetraborat, kemudian dipanaskan. Sampel kemudian ditambahkan $500 \mu \mathrm{l}$ reagen pdimetilaminobenzaldehida (DMAB) dan diinkubasi pada suhu $37^{\circ} \mathrm{C}$ selama 20 menit, selanjutnya ditambahkan $2 \mathrm{ml}$ akuades. Aktivitas enzim ditentukan melalui pengukuran absorbansi menggunakan spektrofotometer UV-Vis pada panjang gelombang $584 \mathrm{~nm}$ dengan $\mathrm{N}$-asetil glukosamin sebagai standar. Satu unit (U) aktivitas kitinase didefinisikan sebagai jumlah enzim yang diperlukan untuk melepas $1 \mu \mathrm{mol}$ $\mathrm{N}$-asetil glukosamin/menit dari kitin (Reissig Jack, and Luis,1955). Aktivitas enzim kitinase ditentukan berdasarkan aktivitas enzim spesifik.

\section{Pengukuran Kadar N-asetil glukosamin}

Kadar $\mathrm{N}$-asetilglukosamin (GlcNAc) ditentukan dengan metode Reissig, Jack, and Luis (1955). Sampel disentrifugasi pada $12000 \mathrm{rpm}$ dengan suhu $4^{\circ} \mathrm{C}$ selama 10 menit dan supernatan sebanyak $500 \mu 1$ ditambahkan $100 \mu \mathrm{l}$ potassium tetraborat, lalu dipanaskan sampai mendidih. Sampel ditambahkan $500 \mu \mathrm{l}$ reagen $\mathrm{p}$ dimetilaminobenzaldehida (DMAB) dan diinkubasi pada suhu $37^{\circ} \mathrm{C}$ selama 20 menit, selanjutnya ditambahkan $2 \mathrm{ml}$ akuades. Absorbansi larutan diukur menggunakan spektrofotometer UV-Vis pada panjang gelombang $584 \mathrm{~nm}$.

\section{Penentuan Kadar Protein Terlarut}

Kadar protein terlarut ditentukan dengan metode lowry. Reagen Lowry terdiri dari Lowry-A dan Lowry-B. Lowry-A disiapkan dengan mencampurkan reagen folin ciocalteau dengan aquadest (1:1). Reagen Lowry B disiapkan dengan mencampurkan $50 \mathrm{ml}$ larutan $2 \% \mathrm{Na} 2 \mathrm{CO} 3+500 \mu \mathrm{l}$ $\mathrm{CuSO} 4+500 \mu 1$ Sodium Pottasium Tartrat. Sampel larutan protein sebanyak $500 \mu \mathrm{l}$ dimasukkan ke dalam tabung reaksi, reagen Lowry B ditambahkan sebanyak $4 \mathrm{ml}$, dan didiamkan selama 10 menit. Kemudian ditambahkan $500 \mu \mathrm{l}$ reagen Lowry A, kocok dan dibiarkan selama 30 menit. Kemudian absorbansi diukur dengan spektrofotometer UV-Vis pada panjang gelombang $600 \mathrm{~nm}$ (Purwanto, 2014).

\section{Analisis data}

Data kuantitatif dianalisis menggunakan Oneway analysis of variance (ANOVA) pada SPSS versi 20.0 dengan batas kepercayaan sebesar 95\% $(\alpha=0,05)$ dan dilanjutkan dengan uji DMRT (Duncan's Multiple Range Test).

\section{HASIL DAN PEMBAHASAN Aktivitas kitinolitik Trichoderma viride yang diiradiasi gamma pada media ko- loidal kitin agar}

Kultur fungi Trichoderma viride pada media padat Potato Dextrose Agar (PDA) yang telah diiradiasi gamma diinokulasi pada media koloidal kitin agar yang diberi indikator Bromo Cresol Purple (BCP). BCP merupakan senyawa kimia halo chromic yang menyebabkan perubahan warna larutan tergantung pada $\mathrm{pH}$ (Agrawal and Kotasthane, 2012). Kultur 
Trichoderma viride tanpa iradiasi gamma (kontrol) dan yang diiradiasi pada 250, 500, 750, dan 1000 Gray berubah warna pada media dari warna kuning menjadi warna ungu dengan intensitas kepekatan yang berbeda-beda (Gambar 1).
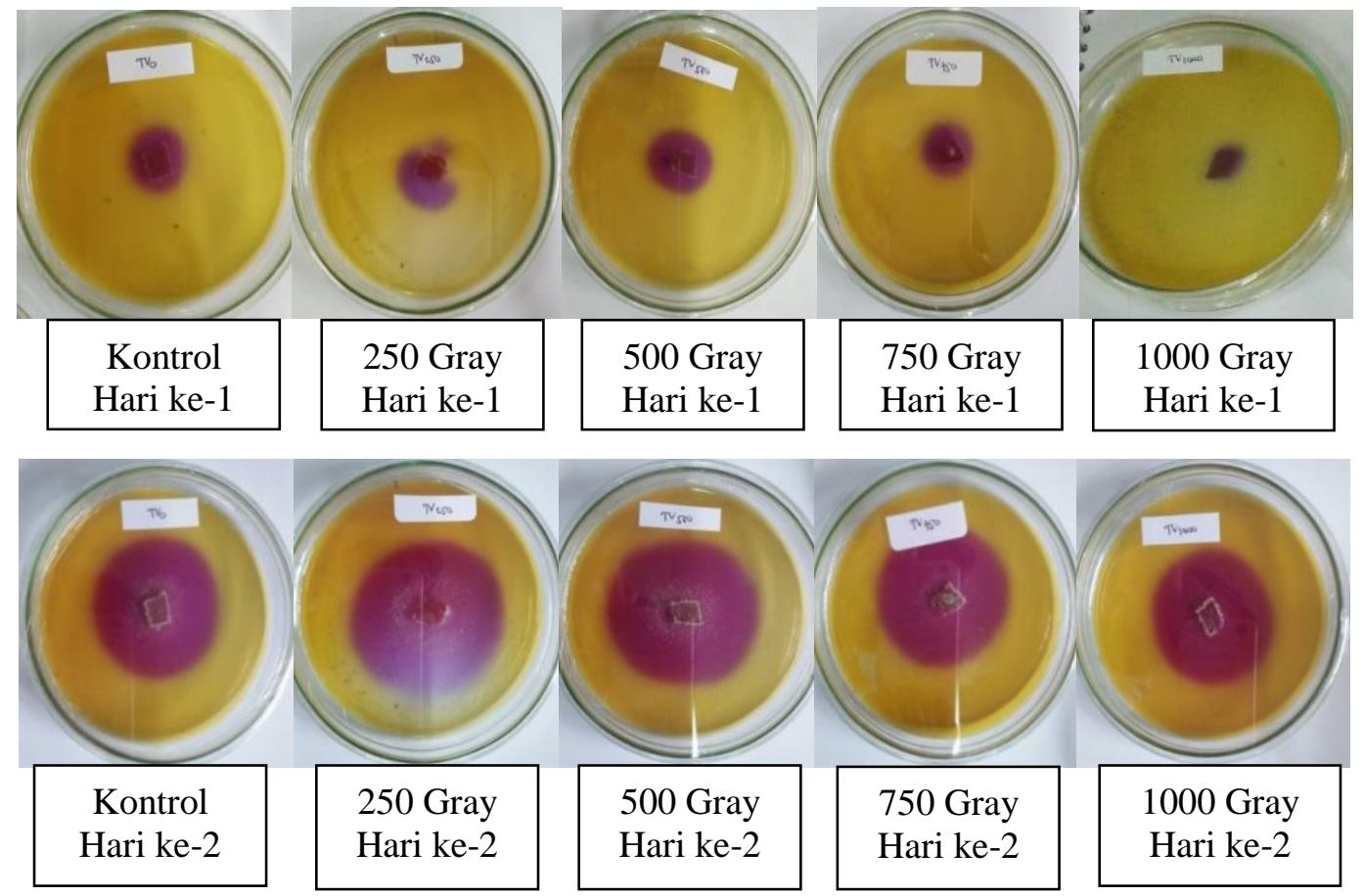

Gambar 1. Aktivitas kitinolitik Trichoderma viride tanpa iradiasi gamma (kontrol) dan yang diiradiasi gamma dengan dosis 250 Gray, 500 Gray, 750 Gray dan 1000 Gray pada media koloidal kitin agar setelah diinkubasi selama 2 hari.

Media koloidal kitin yang mengandung BCP ketika diinokulasi dengan kapang Trichoderma viride mengakibatkan adanya perombakan kitin menjadi $\mathrm{N}$-asetil glukosamin sehingga terjadi pergeseran $\mathrm{pH}$ dari asam menjadi basa yang diikuti perubahan warna media dari kuning menjadi ungu (Agrawal and Kotasthane, 2012).

Kapang yang diiradiasi gamma dengan dosis 500 Gray menunjukkan warna ungu yang lebih pekat, diameter pertumbuhan yang lebih besar, dan memiliki kemampuan mendegradasi kitin lebih cepat dibandingkan dengan dosis lain. Aktivitas degradasi kitin ditunjukkan dengan besarnya diameter zona degradasi pada dosis 500 Gray (Tabel 1). Zona degradasi kitin oleh enzim kitinase pada media koloidal kitin agar menunjukkan peningkatan seiring dengan bertambahnya waktu inkubasi.

Tabel 1. Zona degradasi kitin oleh enzim kitinase Trichoderma viride yang diiradiasi dengan berbagai dosis sinar gamma (Gray) pada media koloidal kitin agar.

\begin{tabular}{clllll}
\hline \multirow{2}{*}{ Hari ke } & Kontrol & 250 Gray & 500 Gray & 750 Gray & 1000 Gray \\
& 2 & 2,25 & 2,75 & 2 & 1,5 \\
2 & 4,75 & 5,5 & 6 & 5 & 4,5 \\
\hline
\end{tabular}

Keterangan: 0 Gray, 250 Gray, 500 Gray, 750 Gray dan 1000 Gray menunjukkan dosis radiasi gamma. 
Trichoderma viride yang diiradiasi dengan dosis 500 Gray memiliki diameter zona degradasi lebih besar dibandingkan dengan dosis lainnya yaitu sebesar $2,75 \mathrm{~cm}$ pada hari ke-1 dan $6 \mathrm{~cm}$ pada hari ke-2. Hal ini menunjukkan adanya perbedaan aktivitas kitinolitik Trichoderma viride pada dosis iradiasi gamma yang berbeda-beda dan pada dosis 500 Gray memiliki aktivitas kitinolitik yang optimum dibandingkan dosis yang lainnya. Penelitian sebelumnya yang dilakukan oleh Abo-State et al. (2010) menunjukkan bahwa Aspergillus niger yang diiradiasi gamma pada dosis 500 Gray dapat meningkatkan aktivitas enzim selulase sebesar $21 \%$ dibandingkan dengan kontrol.

\section{Aktivitas enzim kitinase pada media ko- loidal kitin cair}

\section{a. Aktivitas enzim kitinase}

Aktivitas kitinase diuji dengan mengukur kadar $\mathrm{N}$-asetil glukosamin sebagai produk hasil hidrolisis kitin oleh kitinase menggunakan metode kolorimetrik. Akivitas enzim kasar kitinase menunjukkan peningkatan seiring dengan bertambahnya dosis radiasi gamma. Pada kapang dengan perlakuan irradiasi gamma menghasilkan aktivitas enzim kasar yang lebih tinggi dibandingkan kapang yang tidak diberi perlakuan sinar gamma.

Berdasarkan hasil analisis yang disajikan pada tabel ANOVA menunjukkan taraf signifikansi sebesar $0,01(\mathrm{P}<0,05)$ yang berarti terdapat perbedaan peningkatan aktivitas enzim kasar kitinase pada dosis iradiasi gamma yang berbeda. Hal ini didukung pula oleh uji statistik DMRT (Tabel 2) yang menunjukkan nilai yang berbeda nyata antara kapang Trichoderma viride yang diiradiasi gamma dan yang tidak diiradiasi gamma.

Tabel 2. Aktivitas enzim kasar kitinase Trichoderma viride pada dosis irradiasi sinar gamma yang berbeda.

\begin{tabular}{ll}
\hline Dosis iradiasi gamma (Gray) & Aktivitas enzim kitinase (U/ml) \\
\hline Kontrol & $0,012^{\mathrm{a}} \pm 0,006$ \\
250 & $0,037^{\mathrm{b}} \pm 0,006$ \\
500 & $0,044^{\mathrm{b}} \pm 0,005$ \\
750 & $0,044^{\mathrm{b}} \pm 0,005$ \\
1000 & $0,046^{\mathrm{b}} \pm 0,005$ \\
\hline
\end{tabular}

Keterangan: Perbedaan huruf kecil yang dicetak superscript dalam kolom menunjukkan perbedaan yangsignifikan $(\mathrm{p}<0,05)$ antara dosis iradiasi gamma.

Akivitas enzim kasar kitinase Trichoderma viride yang diradiasi sejalan dengan penelitian yang dilakukan oleh Wahyudi dkk., (2005) yang menunjukkan bahwa pada dosis radiasi 250, 500 dan 1000 Gray dapat meningkatkan aktivitas enzim kiti- nase yang dihasilkan oleh Trichoderma harzianum.

\section{b. Kadar protein terlarut}

Kadar protein terlarut diuji untuk mengetahui jumlah protein terlarut yang terkandung dalam enzim kasar kitinase dan 
untuk mengukur aktivitas enzim spesifik Kadar protein terlarut tertinggi yaitu pada dosis 250 Gray sebesar $0,34 \mathrm{mg} / \mathrm{ml}$ (Gambar 9). Pada fermentasi cair ini menghasilkan kadar protein terlarut yang fluktuatif, terjadi penurunan pada dosis 500 Gray dengan jumlah kadar protein yang terendah yaitu $0,15 \mathrm{mg} / \mathrm{ml}$.

Hasil analisis yang disajikan pada tabel ANOVA menunjukkan taraf signifikansi sebesar $0,000(\mathrm{P}<0,005)$ yang berarti ter- dapat perbedaan peningkatan kadar protein terlarut pada dosis iradiasi sinar gamma yang berbeda. Hal ini didukung pula oleh uji statistik DMRT (Tabel 3) yang menunjukkan bahwa nilai kadar protein tertinggi yaitu pada kapang yang diiradiasi dengan dosis 250 Gray berbeda nyata dengan dosis yang lainnya. Kadar protein terendah terdapat pada dosis 500 Gray dan tidak berbeda nyata dengan dosis 0 dan 750 Gray.

Tabel 3. Kadar protein terlarut Trichoderma viride pada dosis iradiasi sinar gamma yang berbeda

\begin{tabular}{cc}
\hline Dosis iradiasi sinar gamma (Gray) & Kadar protein terlarut $(\mathrm{mg} / \mathrm{ml})$ \\
\hline Kontrol & $0,16^{\mathrm{a}} \pm 0,00$ \\
250 & $0,34^{\mathrm{c}} \pm 0,02$ \\
500 & $0,15^{\mathrm{a}} \pm 0,02$ \\
750 & $0,17^{\mathrm{ab}} \pm 0,01$ \\
1000 & $0,19^{\mathrm{b}} \pm 0,01$ \\
\hline
\end{tabular}

Keterangan : Perbedaan huruf kecil yang dicetak superscript dalam kolom menunjukkan perbedaan yang signifikan $(\mathrm{p}<0,05)$ antara isolat Trichoderma viride.

\section{Aktivitas enzim kitinase spesifik}

Aktivitas kitinase pada kontrol dan dosis iradiasi 250, 500, 750, 1000 Gray diukur berdasarkan aktivitas enzim spesifik yang ditentukan dari nilai aktivitas enzim per mg protein. Trichoderma viride yang diiradiasi gamma pada dosis yang berbeda menghasilkan aktivitas enzim spesifik yang berbeda. Dimulai dari kontrol hingga dosis 250 Gray, aktivitas kitinase mengalami kenaikan sampai mencapai puncak pada dosis radiasi 500 Gray, kemudian mengalami penurunan pada dosis radiasi 750 dan 1000 Gray. Hasil ini sebanding dengan hasil pengukuran protein terlarut yang menunjukkan bahwa pada dosis iradiasi 500 Gray memiliki kadar protein terlarut yang rendah. Perhitungan aktivitas enzim spesifik dipengaruhi oleh kadar protein, semakin rendah nilai kadar protein maka semakin tinggi nilai aktivitas enzim spesifiknya dan begitu pula sebaliknya (Herdyastuti et al., 2009). Hal ini menunjukkan bahwa teknik nuklir dengan radiasi sinar gamma dapat meningkatkan aktivitas enzim ekstraseluler pada kapang berfilamen yang dibuktikan dengan kapang yang diiradiasi memiliki aktivitas kitinase spesifik lebih tinggi dibandingkan kapang yang tanpa perlakuan iradiasi gamma (Baptista et al., 2015).

Berdasarkan hasil analisis ANOVA menunjukkan taraf signifikansi sebesar $0,000 \quad(\mathrm{P}<0,005)$ yang berarti terdapat perbedaan peningkatan aktivitas kitinase spesifik pada dosis iradiasi gamma yang berbeda. Hal ini didukung pula oleh uji statistik DMRT (Tabel 4) yang menunjukkan bahwa nilai aktivitas kitinase spesifik tertinggi yaitu pada kapang yang diiradiasi dengan dosis 500 Gray berbeda nyata dengan kontrol dan dosis 250 Gray tetapi tidak berbeda nyata dengan dosis 750 dan 1000 Gray. Aktivitas kitinase spesifik terendah terdapat pada kapang yang tidak diiradiasi sinar gamma dan tidak berbeda nyata dengan dosis 250 Gray.

Dosis iradiasi gamma 500 Gray merupakan dosis rendah yang mampu memberikan efek stimulasi terhadap pening- 
katan aktivitas enzim kitinase (Sreedhar et al., 2013). Penelitian ini sejalan dengan yang dilakukan oleh Sudrajat dkk, (2016) yang menyebutkan bahwa isolat Tricho- derma viride pada dosis iradiasi 500 Gray memiliki morfologi yang berbeda dibandingkan dengan dosis yang lain.

Tabel 4. Aktivitas kitinase spesifik Trichoderma viride pada dosis irradiasi gamma yang berbeda

\begin{tabular}{ll}
\hline Dosis iradiasi gamma (Gray) & Aktivitas kitinase spesifik $(\mathrm{U} / \mathrm{ml})$ \\
\hline Kontrol & $0,08^{\mathrm{a}} \pm 0,04$ \\
250 & $0,11^{\mathrm{a}} \pm 0,02$ \\
500 & $0,30^{\mathrm{b}} \pm 0,03$ \\
750 & $0,26^{\mathrm{b}} \pm 0,03$ \\
1000 & $0,24^{\mathrm{b}} \pm 0,02$ \\
\hline
\end{tabular}

Keterangan: Perbedaan huruf kecil yang dicetak superscript dalam kolom menunjukkan perbedaan yang signifikan $(\mathrm{p}<0,05)$ antara dosis iradiasi gamma.

Mutasi pada isolat kapang Trichoderma viride yang diakibatkan oleh radiasi gamma terjadi dari dosis iradiasi 250-750 Gray yang ditunjukkan dengan adanya perbedaan pola protein dan pola DNA yang polimorfik pada tiga primer yang berbeda. Kapang yang diiradiasi dengan sinar gamma memiliki kemampuan yang berbedabeda dalam menghasilkan suatu enzim. Perbedaan ini disebabkan oleh adanya keragaman karakter genetik yang terjadi karena mutasi akibat iradiasi gamma (Awan, Nabila dan Ayub, 2011).

\section{Degradasi cangkang telur Haemonchus contortus}

\section{a. Kadar N-Asetil Glukosamin}

N-Asetil Glukosamin merupakan turunan monosakarida glukosa dan monomer penyusun kitin yang berbentuk serbuk putih. $\mathrm{N}$-asetil glukosamin merupakan parameter untuk mengetahui tingkat degradasi kitin oleh enzim kitinase. Enzim yang digunakan untuk uji degradasi cangkang telur yaitu pada dosis 500 Gray karena dosis tersebut memiliki kemampuan aktivitas kitinase spesifik yang paling optimum. Kadar N-Asetil glukosamin yang dihasilkan dari degradasi cangkang telur Haemonchus contortus oleh enzim kasar kitinase selama 48 jam memiliki nilai yang fluktuatif pada semua konsentrasi dengan kadar N-Asetil glukosamin yang rendah. Semakin tinggi konsentrasi enzim kasar yang diujikan pada telur Haemonchus contortus maka kadar $\mathrm{N}$-Asetil glukosamin yang dihasilkan akan semakin besar, akan tetapi pada penelitian ini pada konsentrasi enzim kasar yang tinggi, kadar N-Asetil glukosamin semakin kecil. Keadaan ini diperkirakan karena pada konsentrasi enzim kasar yang tinggi memiliki kemampuan mendegradasi kitin dengan cepat sehingga dalam waktu yang singkat telah banyak N-Asetil glukosamin yang terbentuk, namun $\mathrm{N}$-Asetil glukosamin tersebut dimanfaatkan oleh mikroba lain yang terdapat pada media uji telur sebagai sumber karbon selama masa inkubasi 48 jam (Cholis, Endang dan Ita, 2016). Mikroorganisme lain diperkirakan terbawa pada saat isolasi telur Haemonchus contortus dari feses kambing karena pada kotoran ternak terdapat berbagai macam mikroba (Lingga, 1991).

Berdasarkan hasil analisis ANOVA menunjukkan taraf signifikansi sebesar $0,567(\mathrm{P}>0,005)$ yang berarti perubahan kadar N-Asetil glukosamin dari konsentrasi rendah ke tinggi tidak terdapat perbedaan yang signifikan (Tabel 5). 
Tabel 5. Kadar N-asetilglukosamin yang dihasilkan dari degradasi cangkang telur Haemonchus contortus oleh enzim kasar kitinase dari Trichoderma viride yang diiradiasi sinar gamma

\begin{tabular}{cc}
\hline Konsentrasi enzim kasar kitinase $(\mathrm{U} / \mathrm{ml})$ & Kadar N-asetil glukosamin $(\mu \mathrm{g} / \mathrm{ml})$ \\
\hline 0 & $63,20^{\mathrm{a}} \pm 0,02$ \\
0,06 & $72,23^{\mathrm{a}} \pm 0,02$ \\
0,12 & $99,31^{\mathrm{a}} \pm 0,06$ \\
0,18 & $81,26^{\mathrm{a}} \pm 0,05$ \\
0,24 & $54,17^{\mathrm{a}} \pm 0,00$ \\
0,30 & $54,17^{\mathrm{a}} \pm 0,00$ \\
\hline
\end{tabular}

Keterangan: Huruf kecil yang dicetak superscript dalam kolom menunjukkan perbedaan yang tidak signifikan $(\mathrm{p}<0,05)$ antara dosis iradiasi gamma.

Kadar N-Asetil glukosamin yang rendah bukan berarti tidak terjadi proses degradasi cangkang telur oleh enzim kasar kitinase. Enzim kasar kitinase berhasil mendegradasi kitin dari cangkang telur Haemonchus contortus yang dibuktikan dengan rusaknya seluruh lapisan pada telur Haemonchus contortus. Telur Haemonchus contortus yang tidak diberi perlakuan enzim kasar kitinase, cangkang telurnya tam- pak utuh (Gambar 2A). Kerusakan terlihat pada lapisan kulit terluar vitelin yang tersusun atas protein dan lapisan kulit kedua yang tersusun atas kitin (Gambar 2B). Kerusakan oleh enzim kitinase menyebabkan pecahnya semua lapisan pada dinding cangkang telur dan telur menjadi hancur (Gambar 2C).

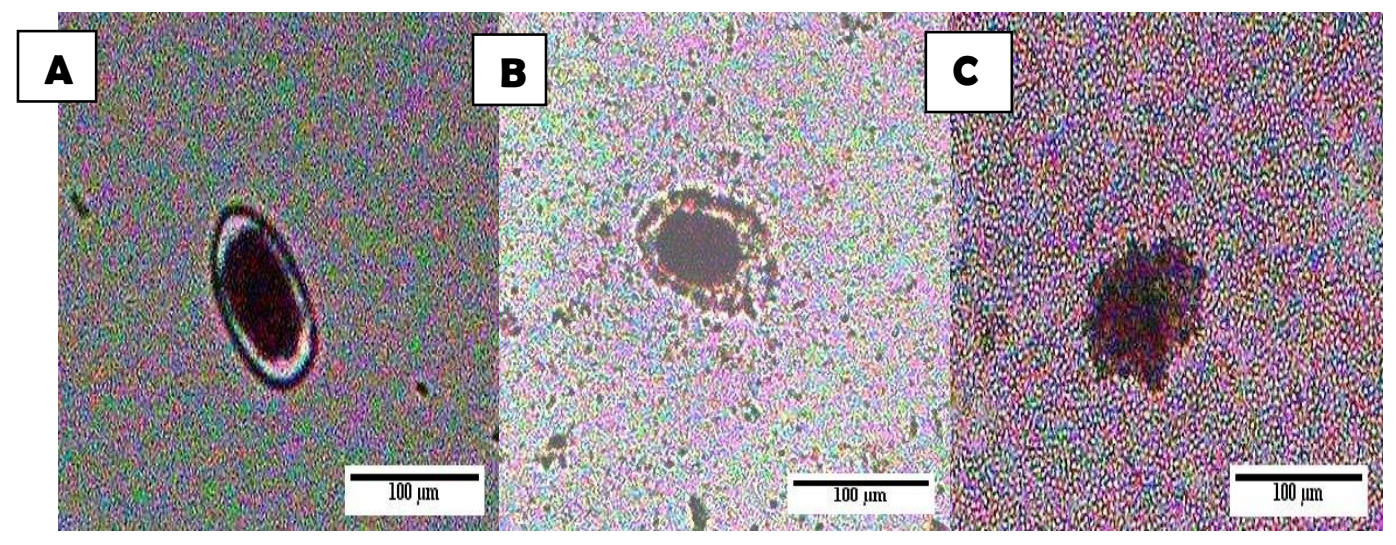

Gambar 2. Telur Haemonchus contortus setelah inkubasi 48 jam, pengamatan pada mikroskop caha dengan perbesaran mikroskop 10x (Skala bar $=100 \mu \mathrm{m}$, Keterangan: a). Telur tanpa perlakuan enzim; b). Cangkang telur mulai terdegradasi oleh enzim kitinase dengan dosis 500 Gray, dan c). Telur hancur terdegradasi oleh enzim kitinase dengan dosis 500 Gray).

Hal ini menunjukkan bahwa enzim kitinase berhasil mendegradasi telur dengan mengurangi komponen sel telur seperti glucan dan kitin (Woo-Jin et al., 2002). Lapisan kitin merupakan lapisan utama yang melindungi isi telur yang berfungsi untuk menjaga keutuhan dan bentuk telur, jika lapisan kitin terdegradasi oleh enzim kitinase maka telur akan pecah atau terjadi penetasan prematur sehingga dapat menurunkan viabilitas larva nematoda (Mercer, Greenwood and Grant, 1992). Enzim kasar kitinase mendegradasi kitin dengan memutus ikatan glikosida yang 
menghubungkan antar monomer pada kitin sehingga terbentuk senyawa yang lebih sederhana dalam bentuk oligomer kitin dan monomer $\mathrm{N}$-asetil glukosamin (Wirawan and Herdyastuti, 2013).

\section{b. Kadar Protein Terlarut}

Kadar protein terlarut pada media uji telur dengan enzim kitinase juga diukur untuk mengetahui seberapa besar kadar protein yang larut dalam media yang dihasilkan dari degradasi enzim pada lapisan terluar telur yaitu vitelin yang tersusun atas protein. Kadar protein yang terlarut dalam media uji telur semakin meningkat dari konsentrasi rendah ke konsentrasi tinggi. Pada kontrol yaitu telur tanpa perlakuan enzim memiliki kadar protein terlarut sebesar $0,05 \mathrm{mg} / \mathrm{ml}$ dan pada telur yang diberi enzim dengan konsentrasi tertinggi yaitu $0,30 \mathrm{U} / \mathrm{ml}$ kadar protein memiliki kadar protein terlarut sebesar $0,14 \mathrm{mg} / \mathrm{ml}$. Kadar protein terlarut yang tinggi membuktikan bahwa lapisan vitelin telah terdegradasi sehingga enzim kasar kitinase akan semakin mudah mendegradasi seluruh lapisan pada telur Haemonchus contortus.

Berdasarkan hasil analisis ANOVA menunjukkan taraf signifikansi sebesar $0,00(\mathrm{P}<0,005)$ yang berarti terdapat peningkatan kadar protein terlarut dari konsentrasi rendah ke konsentrasi tinggi. Hal ini didukung pula oleh uji statistik DMRT (Tabel 6) yang menunjukkan kadar protein terlarut tertinggi terdapat pada konsentrasi $0,30 \mathrm{U} / \mathrm{ml}$ tetapi nilai ini tidak berbeda nyata dengan konsentrasi $0,24 \mathrm{U} / \mathrm{ml}$. Kadar protein terlarut terendah terdapat pada konsentrasi $0,06 \mathrm{U} / \mathrm{ml}$ dan tidak berbeda nyata dengan kontrol.

Tabel 6. Kadar protein terlarut yang dihasilkan dari degradasi cangkang telur Haemonchus contortus oleh enzim kasar kitinase dari Trichoderma viride yang diiradiasi sinar gamma

\begin{tabular}{cc}
\hline Konsentrasi enzim kasar kitinase $(\mathrm{U} / \mathrm{ml})$ & Kadar protein terlarut $(\mathrm{mg} / \mathrm{ml})$ \\
\hline Kontrol & $0,03^{\mathrm{a}} \pm 0,00$ \\
0,06 & $0,05^{\mathrm{a}} \pm 0,00$ \\
0,12 & $0,08^{\mathrm{b}} \pm 0,00$ \\
0,18 & $0,11^{\mathrm{c}} \pm 0,01$ \\
0,24 & $0,13^{\mathrm{d}} \pm 0,01$ \\
0,30 & $0,14^{\mathrm{d}} \pm 0,02$ \\
\hline
\end{tabular}

Keterangan: Perbedaan huruf kecil yang dicetak superscript dalam kolom menunjukkan perbedaan yang signifikan $(\mathrm{p}<0,05)$ antara dosis iradiasi gamma.

Peningkatan protein terlarut menunjukkan bahwa selain enzim kitinase yang bekerja untuk mendegradasi kitin pada lapisan telur yang kedua, terdapat pula enzim lain pada ekstrak enzim kasar kitinase yaitu protease meskipun dalam jumlah yang sedikit. Protease merupakan salah satu enzim yang dihasilkan oleh kapang Trichoderma viride yang terdapat pada ekstrak enzim kasar (Harman et al., 2004). Denaturasi protein menyebabkan sel telur menjadi rentan dan kehilangan sifat permeabilitasnya sehingga lapisan vitelin yang tersusun atas protein dapat terdegradasi oleh adanya protease pada ekstrak enzim yang digunakan (Ekowati et al., 2009). Dengan terdegradasinya lapisan vitelin pada lapisan terluar telur, maka akan mempermudah enzim kitinase untuk mendegradasi kitin pada lapisan kedua telur nematode Haemonchus contortus dan jika lapisan kitin telah terdegradasi maka lapisan lipid akan mengalami kerusakan mekanis sehingga embrio tidak akan berkembang dan hancur. 


\section{KESIMPULAN DAN SARAN}

Terdapat perbedaan peningkatan aktivitas enzim kasar kitinase yang dihasilkan Trichoderma viride pada dosis iradiasi gamma yang berbeda. Pada dosis 500 Gray kapang Trichoderma viride memiliki aktivitas kitinase spesifik yang optimum pada konsentrasi 0,30 U/mg. Enzim kasar kitinase efektif dalam mendegradasi semua lapisan pada cangkang telur Haemonchus contortus dan semakin tinggi konsentrasi enzim kasar yang diberikan maka tingkat kerusakan telur semakin besar.

Diperlukan adanya penelitian lebih lanjut mengenai uji in vivo untuk mengetahui dosis toksisitas enzim kitinase yang digunakan untuk diaplikasikan ke ternak serta bagaimana cara pemberian enzim yang tepat pada hewan ternak.

\section{UCAPAN TERIMAKASIH}

Terimakasih kepada PAIR- BATAN yang telah mendanai segala keperluan terkait penelitian ini dan juga kepada dr. Tri Handayani selaku staff PAIR-BATAN yang telah membantu dalam pengerjaan koleksi telur nematoda.

\section{DAFTAR PUSTAKA}

Abo-State Mam, Aihammad, M Swelim and $\mathrm{Rb}$ Gannam. 2010. Enhanced Production of Cellulase (S) By Aspergillus spp. Isolated from Agriculture Wastes by Solid State Fermentation. American Eurasian J. Agric. \& Environ. Sci., 8(4): 402-410.

Agrawal, T., and Kotasthane, A.S. 2012. Chitinolytic assay of indigenous Trichoderma isolates collected from different geographical locations of Chhattisgarh in Central India. Springer Plus, 1(73), 1-10.

Ahmad, R.Z. 2011. Pemanfaatan cendawan dan produknya untuk peningkatan produksi hasil peternakan. Wartazoa, 21, 81-90.

Ahmad, R.Z. 2013. Kapang Paecilomyces lilacinus dan Verticillium chlamydosporium Sebagai Pengendali Hayati Fasciolosis. Wartazoa, 23(3), 135141.

Ahmad, R.Z., Beriajaya., M. Suatmojo., dan E. Purwaningsih. 2006. Faktorfaktor yang mempengaruhi Aplikasi Duddingtonia flagrans di dalam mereduksi larva Haemonchus contortus di lapang rumput. Seminar Nasional Teknologi Peternakan dan Veteriner, (Hal. 958-979). Bogor.

Awan, M.S., Nabila, T., and Ayub, N. 2011. Gamma radiation induced mutagenesis in Aspergillus niger to enhance its microbial fermentation activity for industrial enzyme production. Molecular Biology Reports, 38, 1367-1374.

Baptista, N.M.D.Q., Solidônio, E.G., Arruda, F.V.F., Melo, E.J.V.D., Filho, J.R.N., Callou, C.M.J.D.A., Miranda, R.D.C.M., Colaço, W., Gusmão, N.B.D. 2015.Effects of Gamma Radiation on Enzymatic Production of Lignolytic Complex by Filamentous fungi. African Journal of Biotechnology, 14(7), 612-621.

Cholis, N., Endang, S., dan Ita, W.N. 2016. Pengaruh penambahan kulturazotobacter pada feses kambing terhadap kualitas media dan produktivitas cacing tanah (Lumbricus rubellus). Jurnal Ilmu-Ilmu Peternakan, 26(2), 30-41.

Dunn, A.M. 1978. Veterynary Helminthology (2nded). London: William Heinemann Medical Books LTD. 
Ekowati, N., Sucianto., E.T., Muljowati, J.S., Dewi, R. 2009. Uji aktivitas antibiosis beberapa isolate Gliocladium dan Trichoderma terhadap mikrob patogen dengan $\mathrm{pH}$ awal fermentasi yang berbeda. Jurnal Inovasi, 3(2), 69-77.

Gomez, R.M., Rojas, A.L.I., Rojas, A.N.G., Cruz, C.R. 2004. Colloidal Chitin Stained with Remazol Brilliant Blue R, a Useful Substrate to Select Chitinolytic Microorganism and to Evaluate Chitinases. Journal Microbiological Methods, 56, 213219.

Gortari, M.C., and Hours, R.A. 2008. Fungal chitinases and their biological role in the antagonismonto nematoda eggs. A review. Mycological Progress, 7, 221- 238.

Harman, G.E., Howell, C.R., Viterbo, A., Chet, I., Lorito, M. 2004. Trichoderma species opportunistic, avirulent plant symbionts. Microbiology, 2(1): 43-56.

Herdyastuti, N., Raharjo, T.J., Mudasir., Matsjeh, S. 2009. Chitinase andchitinolytic microorganism: Isolation, characterization and potential. Indonesian Journal of Chemistry, 9(1), 37-47.

Kertawirawan, I.P.A., Yasa, I.M.R.Y., dan Adijaya, I.N.A. 2012. Efektivitas Penggunaan Ivermectin Untuk Pengendalian Parasit Cacing pada Usaha Tani Penggemukan Sapi Bali. Prosiding Seminar Nasional Teknologi Peternakan, (Hal.48-55). Kementerian Ristek, Jakarta.

Larasati, T.R.D., Mulyana, N., Nurhasni., Hasanah, U. 2016. Pengaruh Radiasi Sinar Gamma Terhadap Kemampuan
Degradasi Lignin Phanerochaete chrysosporium dan Ganoderma lucidum. Jurnal Sains dan Teknologi Nuklir Indonesia, 17(1), 21-36.

Lingga, P. 1991. Jenis Kandungan Hara pada Beberapa Kotoran Ternak. Bogor: Pusat Penelitian Pertanian dan Pedesaan Swadaya (P4S), Antanan.

Lobna, M., and Zawam, H. 2010.Effcacy of somebiocontrol agents on reproduction and development of Meloidogyne incognitainfecting tomato. Journal American Science, 6(11), 495-509.

Mansfield, L.S., Gamble, H.R., Fetterer, R.H.1992. Characterization of the eggshell of Haemonchus contortus. I. Structural components. Comparative Biochemistry and Physiology, 103(3), 681-686.

Mercer, C.F., D.R. Greenwood., and Grant, J.L. 1992.Effect of Plant and Microbial Chitinases on the Eggs and Juveniles of Meloidogyne hapla Chidwood. Nematologica, 8, 227-236.

Muzarelli, R.A.A., and Peter, M.G. 1997. Chitin Handbook. Italy: European Chitin Society.

Nanda, S., and Abraham, J. 2013. Remediation of heavy metal contamination soil. African Journal of Biotechnology, 12(21), 3099-3109.

Narasimhan, A., Suresh, S., Bist, D., and Shivakumar, S. 2013. Enhancement of mycolytic activity of an antagonistic Bacillus subtilist hrough ethyl methane sulfonate (EMS) mutagenesis. Turkish Journal of Biology, 37, 323328. 
Natadisastra, D., dan Agoes, R. 2009. Parasitologi Kedokteran: Ditinjau Dari Organ Tubuh yang Diserang. Jakarta: Penerbit Buku Kedokteran EGC.

Purwanto, M.G.M. 2014. Perbandingan analisis kadar protein terlarut dengan berbagai metode spektroskopi UVVisible. Jurnal Ilmiah Sains dan Teknologi, 7(2), 1-71.

Reissig, J.L., Jack, L.S., and Luis, F.L. 1955. A Modified Colorimetric Method for the Estimation of $\mathrm{N}$ acetylamino Sugars. Journal of Biological Chemistry, 217, 959-966.

Sreedhar, M., Chaturvedi, A., Aparna, M., Kumar, P.D., Singhai, R.K., Babu, V. 2013. Influence of $\gamma$-radiation Stress on Scavenging Enzymes Activity and Cell Ultra Structure in Groundnut Arachis hypogaea L. Applied Science Resource, 4(2), 35-44.

Subandriyo, S., Suhardono, T., and Gray, G.D. 2004. Worm Control for Small Ruminats in Indonesia. In: Sani, R.N., Gray, G.D., Baker, R.L., editors. Worm Control Small Ruminats Trop Asia.Australian center for International Agricultural ResearchScribby Gum Publication, 151-169.

Sudrajat, D., Nana, M., Tri, R.D.L., Rika, H., Almaida. 2016. Karakteristik molekuler kapang Trichoderma viride yang diiradiasi sinar gamma. Prosiding Pertemuan dan Presentasi Ilmiah.Penelitian Dasar Ilmu Pengetahuan dan Teknologi Nuklir, Pusat Sains dan Teknologi Akselerator, BATAN, (Hal 115-123). Fakultas Matematika dan Ilmu Pengetahuan Alam, UNS.

Tehrani, A., Javanbakht, J., Jani, M., Sasani, F., Solati, A., Rajabian, M., Kha- divar, F., Akbari, H., dan Mohammadian, M. 2012. Studi Histopatology Haemonchus contortus di Herrik Sheep Abomasum. Journal of Bacteriology and Parasitology, 3, 144.

Wahyudi, P., U. Suwahyono., Harsoyo., A. Mumpuni., dan D. Wahyuningsih. 2005. Pengaruh Pemaparan Sinar Gamma Isotop Cobalt-60 Dosis 0,251 kGy Terhadap Daya Antagonistik Trichoderma harzianum Pada Fusarium oxysporum. Berkala Penelitian Hayati Journal of Biological Researches, 10(2), 143-151.

Wirawan, A., dan Herdyastuti, N. 2013.Penetuan Waktu Inkubasi pada Pembentukan Senyawa Nasetilglukosamin yang didegradasi secara enzimatis dari kitin. Journal of Chemistry, Univeritas Negeri Surabaya, 2(3), 11-13.

Woo-Jin, J., Soon-Ju, J., Kyu-Nam, A., Yu-Lan, J., Ro-Dong, P., Kil-Yong, K., Bo-Kyoon, S., and Tae-Hwan, K. 2002. Effect of chitinase producing Paenibacillus illinoisensis KJA-424 on egg hatching of root knot nematode (Meloidogyne incognita). Journal Microbiology Biotechnology, 12(6), 865-871. 